\title{
Accessibility of Persons with Disabilities on the Review of Disability Fiqh
}

\author{
Puji Lestari*, Raodah \\ Institut Pesantren Mathali'ul Falah Pati \\ *Corresponding Author: puji@ipmafa.ac.id
}

\begin{abstract}
Accessibility is a form of sympathy and empathy to provide convenience to persons with disabilities by providing friendly public facilities. This study aims to explain how the physical facilities provided by the Institut Pesantren Mathali'ul Falah (IPMAFA) Pati in accommodating people with disabilities in learning and the application of religious fiqh with disabilities. This research is focused on physical facilities in the form of stairs, ramps, doors, classrooms, chairs, tables, laboratories, libraries, toilets, showers, and mosques. This research is qualitative research with descriptive analysis, data collection using observation, interviews, and documentation. Data analysis was carried out by comparing the results of field data with the standards for accessibility of public facilities set by the Ministry of Public Works and disability fiqh. From the results of this study, it was found that IPMAFA had prepared friendly facilities for persons with disabilities however accessibility of facilities is not yet fully adequate and disability-friendly for disabled people who use canes, crutches, and wheelchairs. Facilities that are classified as disability-friendly include stairs, doors, classrooms, tables and chairs, libraries, and laboratories. In the disability fiqh review, the accessibility of taharah, wudhu, and prayer facilities at the IPMAFA is not yet suitable for people with disabilities, whether users of sticks, crutches, or wheelchairs. The results of this study can be a reference for the IPMAFA campus in realizing a disability-friendly campus.
\end{abstract}

Keywords: Disability, Accessibility, Disability Fiqh, IPMAFA

\section{Introduction}

Fiqh, which was previously understood as a comprehensive understanding of all aspects of Islamic teachings, then developed into special knowledge about applicable shari'a that was produced through detailed arguments. (Al-Ashqar, 1991). Jurisprudence studies are related to worship (a servant's vertical relationship with God), mu'āmalah (social interaction), munākahāt (wedding), jināyah (criminal), and siyāsah (political) (Mubarak, 2014). Fiqh can be said as the sign to regulate human life, whether it is in a safe zone in the sense of carrying out lawful, sunnah, and permissive actions or being in a forbidden zone, namely haram. 
Disability Fiqh is one of the fields of jurisprudence that discusses how Islam treats people with disabilities. The term disability fiqh is a new term that has emerged in recent years whose idea was born through studies of the Bahtsul Masail forum. Discussions on religious issues related to persons with disabilities have been carried out since the PBNU National Ulama Council Conference in Lombok in $2017(\mathrm{NU}, 2018$ ) as a form of attention and effort to attract public sympathy for persons with disabilities.

Islam views all humans as the same, namely as khalifatullah who has two functions, namely 'ibādatu Allah (worship Allah) and 'imāqueen al-arḍ (prosper the earth) (Baroroh, 2020). One thing that distinguishes humans is the level of piety in the sight of Allah SWT. One group of citizens who should have the same opportunity and treatment in various lives are persons with disabilities, known as people with disabilities (different able). Law number 8 of 2016 article 1 paragraph 1 states that disability is a physical, intellectual, mental, and/or sensory limitation in the long term which is interacting with the environment can experience obstacles and difficulties to participate fully and effectively with other citizens based on equal rights.

One of the contemporary humanitarian problems is the inadequate protection and fulfillment of the rights of persons with disabilities. Persons with disabilities of all kinds face problems in their lives in the form of limitations in many ways related to themselves, problems of rights as human beings, and the treatment of "normal people" towards them. Being with a disability is not an option, but a reality that must be faced and lived through. Persons with disabilities do not demand too much, they only want equal opportunity. This is in line with the opinion (Tarsidi, 2008):

"People with disabilities do not expect nor need more rights than people in general. They only want to be able to move in their environment with the same level of comfort, convenience and safety as other members of society, have the same opportunity to participate in normal life, be as independent as possible within their limits".

Currently, there are still many public facilities that are not friendly to people with disabilities. This is because disability-friendly public services and facilities are still very limited. Roads, for example, are not fully able to be used comfortably by persons with disabilities. As a Muslim-majority country, Indonesia is also 
considered not friendly in providing facilities and services for religious understanding for persons with Muslim disabilities. The majority of mosques in Indonesia have not provided comfortable access for people with disabilities in carrying out their obligations as a Muslim. The place for ablution, for example, there must be a place for ablution to sit and a place to sit for prayer for those who have difficulty standing.

One of the public facilities that must be designed to be friendly to persons with disabilities is the campus. The Institut Pesantren Mathali'ul Falah (IPMAFA) Pati as a research-based Islamic higher education institution and pesantren values have been designed for people with disabilities. This was stated by the Rector of IPMAFA, Abdul Ghofarrozin, "We are the first Islamic campus to have facilities for people with disabilities". If observed, the IPMAFA campus provides two types of ladder facilities, namely ordinary stairs with steps and disabled stairs or ramps. This staircase is not just an architectural art to beautify the building, but this staircase is indeed provided for people with disabilities.

On the IPMAFA campus, there are several students and lecturers with disabilities who experience disorders and damage to muscles, bones, and joints of the feet and hands so they have difficulty walking normally. Providing access to people with disabilities to continue their studies and develop careers at IPMAFA shows that this campus is towards a disability-friendly campus. For this reason, it is interesting to research IPMAFA, whether it is worthy of being called a disability-friendly campus or not.

This research is qualitative research with a descriptive approach that aims to describe the accessibility conditions for physical impairment in IPMAFA. Research focuses on accessibility infrastructure used for learning and worship such as țahārah, ablution, and prayer because the view is in terms of disability fiqh. In collecting data observation, interviews, and documentation are administered. Data analysis was carried out by comparing the results of field data with the standard of facilities and infrastructure for persons with disabilities by the Regulation of the Minister of Public Works No. 30/PRT/M/2006) and Technical Requirements for Facilities and Accessibility (Minister of Public Works Regulation No. 14 /PRT/M/2017) and disability fiqh. 


\section{Accessibility of a Disabled-Friendly Campus}

Impairment is a condition that is damaged or disturbed as a result of deformation of the bones, muscles, and joints in their normal function. This condition can be caused by illness, accident or it can also be caused by congenital nature (Somantri, 2006). Persons with disabilities usually use assistive devices in the form of wheelchairs, crutches, elbows, braces, or scooters. This tool is very useful to facilitate daily mobility.

According to Murdiyati (2012) quadriplegic is divided into two categories, namely ambulant disabled, which is a disabled person who has limitations when moving from place to place, this quadriplegic does not experience paralysis in all of his limbs, therefore, only uses assistive devices in the form of crutches, sticks, braces, frames are physically disabled) without having to use a wheelchair and wheel chair bound disabled are disabled people who have limitations in doing activities and have difficulty moving around. This disabled person will use a wheelchair to facilitate his daily mobility.

Accessibility (PP No. 43, 1998) is the convenience provided for persons with disabilities to realize equal opportunities in all aspects of life and livelihood. Accessibility is the degree of ease achieved by a person, towards an object, service or environment. The measure of affordability or accessibility includes the ease of time, cost, and effort in moving between places or regions (Muta'ali, 2015).

Accessibility to public buildings in physical form is implemented by providing: (1) Access to, from and inside the building, (2) Doors, stairs, special lifts for multi-story buildings, (3) Parking lots and places to get on and off passengers, (4) ) Toilets, (5) Drinking places, (6) Telephone stands, (7) Emergency warnings, (8) signs or signals. Whereas Article 24 paragraph 1 explains that each organizer of the education unit is responsible for providing equal opportunities and treatment to persons with disabilities to obtain an education. The facilities mentioned above are implemented in buildings, neighborhoods, and other public facilities including services in education.

Persons with disabilities, especially disabled people, also have the same rights in the field of education. So the provision of facilities and infrastructure must be provided for persons with disabilities. Decree of the Minister of Public Works 
Number 468/KPTS of 1998 states that in providing educational facilities and infrastructure it is necessary to pay attention to the following principles of accessibility: (1) Ease, everyone can reach all places or buildings that are public in an environment. (2) Use, that is, every person must be able to use all public places or buildings in an environment. (3) Safety, that is, every building which is general in a built environment, must pay attention to the safety of all people. (4) Independence, that is everyone must be able to achieve.

\section{Disability Fiqh}

Disability fiqh consists of two words, namely fiqh and disability. The word fiqh comes from the Arabic from mașdar (base form) faqiha-yafqahu-fikihan means understand or understand. In term, the science of jurisprudence is al-'Ilmu bi alaḥkām al-syar'iyyah al-'amaliyyah al-muktasabah min adillatihā al-tafșiliyyah (AlMuallifin, nd) it means the knowledge of Islamic laws relating to all forms of human practice which is taken from detailed arguments. Because the point of view studied in this discussion is fiqh, where the source of the jurisprudence reference comes from Arabic literature, the author investigates the terms used for people with disabilities in Arabic.

Islam through the Koran and Hadith does not introduce the term disable or disability specifically. Even the concept of disability fiqh has not become a concern among previous scholars, both in the archipelago and in the world. Hence the term fiqh al-i'āqah or fiqh al-mu'awwaqīn or fiqh zaawi al-iḥtiyājāt al-khāṣahnot found in classical fiqh literature. Religion has provided guidance or methods of worship for people with disabilities as stated in the fiqh books both in matters of 'ubudiyyah, $m u$ 'ämalah as well as others with terms of different types of disabilities, for example, al-'ama (blind), al-abkam (deaf) and so on.

The term disability in Arabic was originally called al muq'ad (disabled people), then changed to żawi al-'āhah (people who have physical disabilities). Furthermore, the naming of people with disabilities becomes-'ajjiz (weak people) because of their physical deficiencies so that the community considers people with disabilities to be weak. As society develops and the community's perspective on 
disability, then the term used for disability is more positive and dynamic, namely the termẓawi al-ihtiyājāt al-khāṣhah (those with special needs) (Al-Huli, 2007). Thus, disability fiqh is a law relating to the practice of persons with disabilities which aims to protect and grant their rights. The disability fiqh paradigm views that fiqh should be read as a means to solve the problems of persons with disabilities as well as for the general benefit.

Fiqh is not a dogmatic-normative concept but a progressive and responsive concept to the times (zaenurrosyid, A dan Sulikhah, 2017). In fiqh, there are three very essential factors. First, fiqh is the most dynamic science, because it is a moral guide for the ever-changing and competitive social dynamics. Second, fiqh is very rational, because it is a scienceiktisābi(science results of studies, analysis, and research). Third, fiqh is a science that emphasizes actualization or what is commonly called 'amaliyah which is practically every day (Fikri, 2015).

Several rules (Qawa'id fiqhiyah) which is the basis for establishing a good law relating to the problem 'worship, mu'ämalah and others include (1) Al-ḍararu yuzālu means that the danger (must) be eliminated; (2) Dar'u al-mafāsid aulā min jalbi almașālih. The point is preventing damage must be more than taking advantage; (3) al-Darūrāt tubīhu al-Maḥz̄ūrātthat is, a forced case (any harm) allows things that are prohibited; (4) al-Masyaqqatu tajlibu al-taisir aThe point is that difficulties in Islamic law make it easy; (5) iżā ḍāqa al-amr ittasa'a meaning that if a case becomes narrow, then the law expands (As-Suyuthi, 1403).

According to Risplem-Chaim (2007), the fiqh view of cases of persons with disabilities is discussed as something flat, devoid of emotions, because the fact that disability is part of God's will that must be accepted.

"... the disabilities are always mentioned as a matter of fact, as part of the reality that people are meant to live in, as a result of the divine wisdom and planning with which Allah manages the creation. No emotional attitude, such as remorse, anger, despair, or disappointment, accompanies any of the discussions of disabilities within the legal literature." (Rispler-Chaim, 2007).

The limitations of fiqh performance against disabilities are as follows: (1) Not being able to carry out one or more pillars of worship. For example, being unable to stand in prayer, incapable of prostration, incapability of țawaf, and so on. (2) Not 
being able to fulfill one or more of the requirements of worship due to limitations. (3) Diseases that endanger others, for example, mental disorders that can hurt others. (4) Endangering disabilities if they continue to do so. (5) Disabilities that cause the person to be unable to earn a living. It is permissible to give zakat to him provided that no one can support him (Darwīsy, 2017).

Based on the above limitations, jurisprudence provides dispensation for disabilities in performing worship in the form of (1) Performing worship according to their abilities, (2) Postponing the implementation of worship, (3) Representation of its implementation, (4) Abolishing of obligations. Because all the laws declared by Islam and all elements that help the implementation of Islamic law are none other than aimed at achieving the benefit of the people (Solihin, 2020). Towards persons with disabilities, fiqh shows a tolerant attitude, accepting them as they are, accommodating their special needs, so that they understand that they cannot fulfill the religious obligations of a Muslim (Maftuhin, 2011).

Laws relating to disability are interpreted with al-marị law (a sick person) who may pray while sitting down, even his obligation to fail is due to intellect. The term disability fiqh has only recently appeared in circlesfuqah $\bar{a}$ ' contemporary. The factors that cause the unanswered concept of disability in the viewpoint of jurisprudence are because first, jurisprudence is too focused on the issue of fulfilling human obligations, and not on rights that deserve to be received, and second, the jurisprudence legal subject is in the form of an individual, not an institutional obligation (Hadi, 2016).

\section{Accessibility with Disabilities in Learning at IPMAFA Stairs, Ramps, and Doors}

Amenities campus stairs meet the uniformity standard of $7 \mathrm{~cm}$, and there are no stairs with holes that can endanger quadriplegic. Judging from the handrail, the height of the propagation exceeds the ministerial requirements, namely $65-80 \mathrm{~cm}$, but the IPMAFA ladder handrail design is more flexible, namely by providing eight levels of horizontal iron which are the choice of quadriplegic to be used as a handle according to their height. Every $8 \mathrm{~cm}$ there is a vertical iron barrier in the shape of the letter "o", this barrier does not only function for art or to beautify the handrail 
motif but has a limiting function so that the user of the ladder does not fall directly on the handle.

Made from strong materials and a surface that is easy to handle and not slippery, this handrail is suitable for persons with disabilities. However, the propagation handle which should have been increased in length at the ends (top and bottom) by $30 \mathrm{~cm}$, was not found on the handrail at IPMAFA. Judging from the width of the stairs, the height, and width of the steps, it meets the standards, namely that the width of the stairs does not exceed $220 \mathrm{~cm}$ and the height of the steps is not more than $18 \mathrm{~cm}$.

Meanwhile, the existence of a ramp on campus is at the entrance to the left lane. The components of the ramp, namely the handrail and borders, are available, this ramp does not have a safety edge. The maximum ramp width of $120 \mathrm{~cm}$ must have a safety beside it, while the IPMAFA ramp has a width of $153 \mathrm{~cm}$. When viewed from the slope, the ramp exceeds $6^{\circ}$, the slope is almost double the specified standard. Likewise, at the landing, the length of the ramp with a size of $900 \mathrm{~cm}$ must have a landing as a rest area for ramp users, but the size is $1.150 \mathrm{~cm}$, there is a new border. This shows the ramp on the building IPMAFA campus has not fulfilled the disability ramp eligibility.

Field observations obtained the results of the size of the door width of classrooms, rectorate rooms, faculty and study programs, laboratories, and libraries that meet the standards. The door to the KPI laboratory, which has two steps in front of it, should be given a handle on the edge of the door so that it can help disabled persons access it.

\section{Classroom}

Spacious classrooms, flat floor surfaces, are not slippery, giving freedom to persons with disabilities in carrying out activities in them. People with physical impairments, both using crutches and wheelchairs, do not have difficulty moving and have difficulty accessing all areas of the room including the blackboard area. The height of the blackboard can still be reached by wheelchair users even though it is only the area under the blackboard. Apart from whiteboards, other projection tools available television can be an alternative as a substitute for whiteboards. 
Chairs and tables in the classroom are not permanent and easy to move, making it easy to change positions or move tables and chairs when they are not in use. Another convenience of student chairs and desks is that they can be folded, disabled wheelchair users who do not need a classroom chair can occupy a place freely because if the chair is not used it can be folded easily. Thus the classrooms remain spacious and comfortable for learning.

\section{Laboratory}

The laboratory at the Mathaliul Falah Islamic Boarding School has a basic room size according to the standards imposed by the Minister of Public Works Regulation number 14 of 2017 . The lighting in the laboratory in each faculty has bright lights but does not make glare. Accessibility is also easy to reach for people with disabilities using wheelchair, cane, or crutches. There is one laboratory, namely the Islamic Communication and Broadcasting Laboratory, which uses a ladder in front of the entrance, this causes disabled wheelchair users to have difficulty using it. Likewise, the users of sticks or crutches have a little trouble because the sidewalls of the door are not facilitated with a handle.

The language laboratory and micro-teaching on the control table are positioned higher than the floor, this does not affect the accessibility of students with disabilities. This situation makes it very difficult for wheelchair users to access it, but users of crutches or sticks can easily access it. On the front of the microteaching which is used by the practitioner for teaching practice, it is not an obstacle for disabled wheelchair users.

\section{Library}

In general, the library room is designed in such a way as to take into account building users who have physical limitations, especially with physical disabilities. The entrance to the library is designed using 2 doors, the type of sliding door. The door handle in the library can be reached by persons with disabilities even if they use a wheelchair. Access to the reading room and reference room is through the screening door, at this door the size is a little narrow and there is a cable connection, making it difficult for persons with disabilities to access using wheelchair aids, but still easily accessible for persons with disabilities using tools help sticks or crutches. 
The IPMAFA Library has a reading room that can be easily accessed by persons with disabilities and uses bright but not glare lighting. The floors in the library are not made of slippery materials. The room is cool and not noisy, providing comfort for those who read and work on tasks that must be completed.

\section{Analysis of the Accessibility of Thaharah with Impairment}

Referring to the regulation of the minister of public works number 14/PRT/m/ 2017 concerning the size of the space for the quadriplegic using crutches and wheelchairs. The width of the space for the quadriplegic using crutches is at least $95 \mathrm{~cm}$. The width of the space for the quadriplegic using wheelchair aids is at least $120 \mathrm{~cm}$. Meanwhile, the data obtained in the field show that the width of the toilet doors at the IPMAFA varies, namely 95, 74, and $63 \mathrm{~cm}$. Only the size of the lecturer's toilet door meets the standards for persons with disabilities who use crutches, as, for wheelchair users, the size of the toilet door does not meet the standard.

The floor on the toilet already uses non-slippery materials, the lower floor design with an entrance. This indicates that there is a restriction on the restroom area so that the water used by the stool does not come out of the area so that unclean is not scattered everywhere. Access to the toilets for lecturers and students is not an obstacle because the floor is flat. However, access to mosque toilets is an obstacle for disabled users of crutches and wheelchairs because there are no ramp and handrail facilities.

Impairment is a person with a disability who has limited legs; generally disabled people use their hands as a support tool. Therefore it requires a vine handle. In campus toilets and mosques, there are no handrails that can assist the disabled in purifying or accessing the toilet. Also, the existing toilet uses a squat toilet, where squatting is an activity that cannot be done by disabled users of assistive devices, both crutches, and wheelchairs.

The purifying pool which is located at the front of the mosque toilet has a function to clean the unclean ones on the feet, the bottom of the canes, and wheelchairs. When passing through it, if the unclean thing that is attached easily 
falls, then the unclean thing automatically decays so that the feet become holy again. In the campus mosque toilets, there was no such pool.

The wheel of a wheelchair and the bottom of a stick in all its forms are always not condemned to be unclean when it touches the ground, asphalt, roads with various conditions. This is as disclosed(Asy-Syarbini, n.d.) "Al-țina al-syawāri 'almutayaqqan najāsatahu yu'fa' anhu 'ammā yata'ażżaru al-ị̣tirāzu minhu gāliban wayakhtalifu bi al-waqti wamauḍi'ihi min al-saubi wa al-badani" means "Highway land which is believed to be unclean as long as it is difficult to avoid under normal circumstances. The enforcement of this $m a^{\prime} f u$ law varies according to time and place on the body and clothes ". Thus it can be said that the IPMAFA toilet facilities have not met the toilet standards for disabled persons with assistive devices.

The disabled (do not have hands and feet) perform ablution by washing the remaining members of the ablution (if the remaining members are above the elbows, then it is Sunnah to wash on them). But if the conditions are not possible to do it yourself, then look for someone to perform ablution, either for free or at a cost. Meanwhile, if you have not found someone who can help him perform ablution or do not have money to pay for them, then he may pray without wudu but must repeat the prayer when it is possible to perform ablution.

Impairment has limitations in standing, therefore requires a chair or other seat in the process of ablution. This facility has not been provided by the campus in the shower area or at the place of ablution. Although wheelchair users can use their wheelchair for seating, access is not supported. It can be seen that there is a floor divider in the shower area with a height of $16 \mathrm{~cm}$ which does not allow chair users to pass. Even the area where the mosque is ablution must be accessed via stairs first without any alternative routes such as ramps for people with physical disabilities.

This is very important because ablution is a prerequisite for prayer. A person will not validate his prayer if he has not performed ablution. Besides that, the obstacles and difficulties as mentioned above are the main reasons for many people with disabilities to leave worship in mosques or come to scientific assemblies. These difficulties can be overcome by providing disability-friendly public facilities. 


\section{Accessibility of Persons with impairment Prayers}

The mosque is one of the facilities used to perform prayers which must always be kept pure. One of the prerequisites for prayer is the sanctity of body, dress, and place. This is not a problem for normal converts or those with physical perfection, but a problem for disabled people who use assistive devices in the form of prosthetic limbs, sticks, crutches, or wheelchairs. Fiqh provides many dispensations and alternatives that can be chosen and places a person according to their condition so that there is no reason to leave the obligation due to physical limitations.

The path to the prayer area or the interior of the mosque is not disabledfriendly, especially with physical disabilities, this can be seen from the width of the staircase surface of the IPMAFA's stairs, which is still too narrow, which is $30 \mathrm{~cm}$ for crutch users, whose width requires $120 \mathrm{~cm}$ according to the regulation of the minister of public works. number 14 /PRT/M/2017, the absence of a handrail also makes it difficult for disabled people to climb stairs. Also, for disabled wheelchair users, the facilities are not yet available, namely in the form of a ramp or a special lane for wheelchair users.

To maintain the comfort of the congregation praying at the mosque, the IPMAFA campus divides the prayer area into a women's area and a male congregation area. The large room makes the congregation free to carry out worship activities in this mosque both standing and sitting. Alluding to the prayer that is performed while sitting as in the hadith of the Prophet regarding the permissibility of praying while sitting for people who are unable to stand. The meaning of "sitting" provides various interpretations, namely sitting on the floor or sitting on a chair. All of these interpretations are correct from a fiqh perspective. Withdrawal can perform prayers sitting on the floor or sitting in a chair or wheelchair. In this case,

In the view of disability jurisprudence, persons with disabilities are allowed to bring aids in the form of sticks, crutches, or wheelchairs into the mosque on the condition that the aids are holy and do not carry unclean. If the tools used are only dirty due to dust or soil, not unclean, it is necessary to first clean all dirty parts as much as possible. Because this is just ordinary dirt, open it unclean, then you don't have to use water but you can use other media such as tissue or cloth. However, if it 
is obvious that there is something unclean on the part, then it must first be purified without needing to be removed from the body. How to wash it can use water in a bottle so that it is not difficult.

\section{Conclusion}

After collecting and analyzing data, it can be concluded that the accessibility of learning facilities at the Institut Pesantren Mathali'ul Falah is partly friendly to people with disabilities and some are not yet proper and friendly for people with disabilities who use canes, crutches, and wheelchairs. Meanwhile, in the disability fiqh review, the accessibility of taharah, ablution, and prayer facilities at the IPMAFA is not yet suitable for people with disabilities, whether users of sticks, crutches, or wheelchairs.

\section{References}

Al-Ashqar, U. S. (1991). Tarikh al-Fiqh al-Islami. Maktabah al-Falah.

Al-Huli, M. H. (2007). al-Mu'aq fi al-Fikr al-Islāmī. Mu'āqūnā Masyākil Wa Hulūl.

Al-Muallifīn, M. min. (n.d.). al-Fiqh al-Muyassar fï Dau al-Kitāb wa al-Sunnah. Majma' al-Malik Fahd li Țiba'ah al-Mușhaf al-Syarīf.

As-Suyuthi, J. (1403). al-Asybāh wa al-Naẓāir. Dār al-Kutub al-'Ilmiyyah.

Asy-Syarbini, M. K. (n.d.). Mugni al-Muhtāj. Dar al-Fikr.

Baroroh, U. (2020). Understanding Methodology of Fiqh Sosial. Santri: Journal of Pesantren and Fiqh Sosial, 1(1).

Darwīsy, A. M. bin 'Abdur R. (2017). Fiqh al-Muwāzanāt liżawi al-I'āqah: Dirāsah Taṭīiqiyah fi al-'Ibādāt. Majallah Ad-Dirasat Al-Islamiyyah, 29.

Fikri, A. (2015). Resensi Buku Fikih (Ramah) Difabel. Inklusi, 2.

Hadi, M. K. (2016). Fikih Disabilitas: Studi Tentang Hukum Islam Berbasis Mașlahah. Palastren, 9.

Maftuhin, A. (2011). Difabilitas dalam Fiqh. Seri Kajian Difabilitas PSLD UIN Sunan Kalijaga Jogjakarta.

Mubarak. (2014). Fikih dalam Watak Formalistik dan Sufistik. Islamic Review: Jurnal Riset Dan Kajian Keislaman, 3(1).

Murdiyati, D. S. (2012). Aksesibilitas Sarana Prasarana Transportasi yang Ramah bagi Penyandang Disabilitas pada TransJakarta. Universitas Atmajaya.

Muta'ali, L. (2015). Teknik Analisis Ragional Untuk Perencanaan Wilayah, Tata Ruang, Dan Lingkungan. Badan penerbit Fakultas Geografi (BPFG) Universitas 
Gajah Mada.

NU, L. B. M. (2018). Fiqh Penguatan Penyandang Disabilitas. Lembaga Bahtsul Masail NU.

Rispler-Chaim, V. (2007). Disability In Islamic Law. Springer.

Solihin, K. (2020). Analisis Kebijakan Sertifikasi Produk Halal dalam Perspektif Perlindungan Kemaslahatan Umat. Islamic Review : Jurnal Riset Dan Kajian Keislaman. https://doi.org/10.35878/islamicreview.v9i1.188

Somantri, S. (2006). Psikologi Anak Luar Biasa. Refika Aditama.

Tarsidi, D. (2008). Aksesibilitas Fisik bagi Penyandang Ketunaan.

Zaenurrosyid, A dan Sulikhah, S. (2017). Paradigma Fiqh Sosial atas Kemiskinan dalam Gerakan "Empowering” Menuju Kemakmuran Umat. Jurnal Islamic Review, 6(1). 